\title{
Review International Trade Includes Business Strategy and the Role of International Organizations
}

Johnwey Andelekke ${ }^{1}$, Mkamzee Gichuru

Faculty of Management Science University of Nairobi, Kenya

*Corresponding Author: Johnwey Andelekke

Received: March 11, 2021

Revised: April 3, 2021

Accepted: April 28, 2021

\section{Abstract}

The aim of this article is to include an overview of international business, with a particular emphasis on strategic international business and organizations. This evolution is mostly attributed to the advancement in research and tracking technologies, which are expanding in lockstep with the evolving attitudes and thoughts of increasingly evolved humans. As a part of this transformational phase, nations must collaborate on both national and regional levels. The aim of this article is to include an overview of international business, with a particular emphasis on strategic international business and organizations. No such thing as a pure national economy exists. The majority of the planet is much too large to dismiss as a consumer or a rival. As a result, we are obligated to educate students about foreign perspectives in order for them to comprehend global economic trends.

Keywords: Project Management, Construction, Components And Characteristics

\section{Introduction}

Trade activities that lead to economic interdependence between nations. A global economy can not be seen as an expansion of commerce between nations, since what is occurring is the consolidation of the international economy into a centralized economy, economy, and industry. As a result, there is no longer a pure national market. The majority of the planet is much too large to dismiss as a consumer or a rival. As a result, we are obligated to educate students about foreign perspectives in order for them to comprehend global economic trends. Regardless of the debates surrounding open markets and the world market, From a legal standpoint, government approval of the WTO is a proven legal reality based on the government's political will to promote an unavoidable free trade system. This evolution is mostly attributed to the advancement in research and tracking technologies, which are expanding in lockstep with the evolving attitudes and thoughts of increasingly evolved humans. As a part of this transformational phase, nations must collaborate on both national and regional levels. The aim of this article is to include an overview of international business, with a particular emphasis on strategic international business and organizations. This evolution is mostly attributed to the advancement in research and tracking technologies, which are expanding in lockstep with the evolving attitudes and thoughts of increasingly evolved humans. As a part of this transformational phase, nations must collaborate on both national and regional levels. The aim of this article is to include an overview 
of international business, with a particular emphasis on strategic international business and organizations. This evolution is mostly attributed to the advancement in research and tracking technologies, which are expanding in lockstep with the evolving attitudes and thoughts of increasingly evolved humans. As a part of this transformational phase, nations must collaborate on both national and regional levels. The aim of this article is to include an overview of international business, with a particular emphasis on strategic international business and organizations.

\section{Definition of International Trade}

Traders play a critical part in meeting human needs. This merchants will sell manufactured products to customers. They purchase products to resell without altering their form or shape, a process known as trading. Trading operations have been extremely diverse in recent years. Trade has infiltrated the borders of nations (international). International trade is the practice of trading products or services between countries. There are exporters and importers involved in the trade between these nations.

Several figures also advanced hypotheses regarding the origins of foreign trade as forces that promote trade between countries. Adam Smith and David Ricardo are two of these figures. Full Benefit Principle (theory of absolute advantage). If a nation may manufacture products or services that other countries cannot, that country is considered to have an absolute superiority over other countries. Meanwhile, David Ricardo suggested the Principle of Comparative Advantage as a theory of foreign exchange. According to David Ricardo, a nation has a competitive advantage whether it is capable of producing a product or service more effectively and at a lower cost than other nations.

Distinction of Taste

Even if all countries' output conditions are identical, each nation can exchange if their tastes vary. Norway, for example, exports beef, while Sweden exports fish. Both countries would prosper from this exchange, which would result in a rise in the number of satisfied citizens. Market Expansion, If all internal demand for a good has been met, the only way to address surplus supply and increase profit is to exploit international markets. Benefits of Specialization,each nation has distinct advantages (absolute or comparative) in manufacturing certain types of products or services, and therefore greater benefits can be realized by specialization.

\section{Definition of impact and international trade law}

International Trade's Impact Economists assert that this foreign commerce has an impact on the countries concerned. This effect is both positive and negative. International trade law is a set of laws that control foreign affairs which are based on civil law or the law that regulates international dealings between countries (Buthe, 2010; Bonell, 2001; Cutler, 2002). The preceding description demonstrates unequivocally that the laws are documentary, implying that chmitfhoff makes a direct distinction between civil and republican law.

\section{The Impact of International Trade on the Economy}

international exchange is the practice of trading or purchasing and selling products or services 
between two countries with the aim of satisfying the requirements of the buyer or seller and seller, and doing so in order to earn benefit (Waugh, 2010). The occurrence of foreign exchange depends on the variations that are seen in these four main areas, resource factors: natural capital, human resources, history, research, the costs of output, and markets, and employment, and production and prices. In foreign exchange, shipments and imports, export and import processes are done. With currency from another nation, the manufactured products would be accounted for. foreign currency is used as a way of paying for goods and services overseas. Purchasing international products is one of the most basic reasons for the use of foreign currency, one must compensate for in order to use, the others are for paying foreign transactions, to pay for purchases overseas, and repayment of loans to officials are often used for that type of activities This concept relates to each exchange-based trading partner. A country could gain from the flow of imports and/exports or face losses on the likes of further overall economic activity or competition from exporting and importing countries. The size of a country's economy is highly dependent on the various governmental agencies differs.

Having free trade has helped the country to increase its production and quality, and supply, and increased the proportion of the population, however these things can also decrease its GDP and national economic stability; it's just that GDP and National Product may also be hurt in the same way; not just exports and imports, but also exports and imports have increased, which encourage the economy, such as import duties and export duties and commercial imports, make it cheaper; for the country to develop, people must be paid and the population must be distributed fairly, while foreign exchange is gained; there is an immediate threat to cooperation between people; likewise, the emergence of new technologies will result in more employment but will lead to redundancies.

The negative impacts of international trade include: (a) The country loses its domestic products due to cheap imports from abroad, which means the domestic industry suffers losses; (b) Entanglement in global markets, due to which one's dependence on foreign countries; (c) Favored; (d) If it cannot beat them, the others, the country's economic growth would be low and the number of jobless people will rise.

\section{How to Deal with the Impacts of International Trade With Barriers- Trade Barriers}

There are two common ways a country can restrict foreign products: (1) The determination of import levies, commonly known as tariff barriers. (2) Restriction of goods through special regulations known as non-tariff barriers (NTBs).

\section{Principles Of International Trade Law}

As was observed, trade economies generally are divided into export-led and import-oriented economies, developed and developing countries can be described as those that implement and expand trading policies guided by principles of international trade law (Mavroidis, 2015; Hopkins, 2012; Barnet \& Cavanagh, 1995).

It's understood that foreign trading would present challenges and of course. When countries that adhere to procedural law come into contact with countries that adhere to the common law, litigation takes place within them instead of within the civil law jurisdictions. After that, how can 
the problem be solved? In the picture below, we will go through the following ideas. This book is written for: Anybody who is interested in Expanding their Consciousness (Countries, International Trade Organizations, Individuals, International Companies and Banks).

Two countries could be struggling in the realm of law: conflicts may exist in any one or more of three ways, each of which may be pursued as a third alternative solution. making an option under International Trade Law

\section{Unification}

expansion is one in which there is a merger and abolition of the previous regime with a new system of laws The rules have little to do with the intention of determining who should prevail, but are established on international law. It is mandatory for all nations to conform to the contents of this international agreement's laws in their domestic legal codes. and elucidation of the definition of Unification: Intellectual property rights The purpose of this agency is to safeguard Patents, Copyright and Trade Secrets, and the tasks it carries out are to enforce the Agreement on Trade Related Aspects of Intellectual Property Rights (TRIPS).

\section{Harmonization}

harmonization involves the search for an underlying unity or other key concepts that can be articulated through different legal frameworks and manifests itself as such (at this point, they're working together or they have converged (mistelis, 2000;taruffalos, 2012) ). When searching for concepts in various legal systems, social, environmental, and administrative law, bear in mind their varied implications and then establish them as general values. Agreement goes hand and hand with treating others fairly the Stichtungler/comparative Stichtler's method of unification and harmonization Many treaties and agreements utilize the application of international law to create national law. For example, such as the TRIPS and WTO agreement Legal codes which allow an identical implementation across various domains of rules in multiple locations similarly interpreted agreements on commercial agreements; (in addition to this) example: the United Nations' Model Law on International Arbitration incorporates a provision that allows the use of existing contracts, thereby giving states freedom to enforce it uniformly The document known as the Uniform Customs and Practice (also known as UCP, or INCOTERP) was implemented by the objects of international law, which specified procedures and documentation requirements for financial clearing and forwarding services provided by customs.

\section{Steps That The Government Should Take In Anticipating Free Markets}

The following measures must be taken by the government in anticipation of the free market: (1) In the era of free trade and globalization, both policymakers and practitioners in the field of international trade are needed to provide an international perspective; (2) Given the trends in the international arena, it is clear that national interests must be fought more effectively and safely in the context of all nations' interdependence. Intercontinental; (4) Attempts to establish mutually advantageous and orderly trading ties necessitate changes to the national laws and regulations of each country involved.

In foreign trade or free trade, a political strategy must be implemented to ensure constant economic prosperity and peace. There are many government policies in international trade or 
free trade. The arguments for maintaining foreign exchange or open trade are as follows: (1) Classical philosophy, which addresses Adam Smith's concept of total benefit and David Ricardo's concept of productivity and manufacturing costs. (2) Modern philosophy asserts that capital and labour are significant forces of productivity.

In international trade or free trade in export activities, one must take action or implement a policy to regulate the rate of entry and exit of goods from outside the country. Some policies for regulating the rate of exports include the following: (1) diversification; (2) market share expansion; (3) quality improvement; (4) product diversification; and (5) devaluation.

\section{Government Interference in the Free Market}

As a result of some of the free market's failures, economists would consider government intervention in the market to regulate economic behavior. Government action is meant to supervise economic development in order to prevent negative external consequences. Provide sufficient public goods to allow citizens to purchase them easily and affordably, Supervise the operations of the corporation, particularly large businesses with market influence; Ensure that business activities do not result in social inequality; and Ensure that economic development can be accomplished effectively.

The government will intervene in the economy in three ways: (1) Make rules. Laws are needed to improve the efficiency of business mechanisms, to develop socioeconomic foundations, and to promote open competition in order to prevent monopoly power; (2) directly carrying out commercial operations (establishing companies) through the production of public goods; and (3) carrying out fiscal and monetary policies. The city needs fiscal policies in order for the government to reconcile its spending budget and state income. Monetary policy is needed to maintain market stability. However, monetary policy is ultimately about the position of capital in economic development. Governments should use fiscal and monetary policies to accomplish the following goals: (1) Increase the productivity in which output factors are used; (2) Equal distribution of income; and (3) Overcoming macroeconomic challenges that often occur, such as unemployment, inflation, and others.

\section{International Organizations}

An international organization is a group of countries established to improve the order of international affairs in areas such as trade, socioculture, science and technology, and defense, among others. Each organisation performs unique functions, but multinational organisations in general perform the following eight functions. International organisations should serve as dialogue and negotiating platforms, allowing each participant to engage in the process of articulating and aggregating his country's priorities in the form of international affairs.

International institutions should define human standards and ideals that must be adhered to by not just their representatives, but also the rest of the world. Additionally, foreign organisations play a critical role in attracting entrants to the international political structure. An international organization's socialization work is carried out by gradually passing those ideals to all of its participants.

International organisations often make decisions by evaluating and responding to prior activities, 
ad hoc arrangements, and so forth. International bodies often serve to ratify a variety of laws that can be implemented in the international community, including those related to judiciary agencies with a judicial role. Each member country of international organizations has the same responsibility for identifying, gathering, analyzing, and disseminating knowledge in the public interest. Under the UN agency, many agencies perform organizational roles, such as UNICEF (child protection) and UNHCR (humanitarian assistance) (addressing refugee problems). Additionally, there are foreign organisations that serve as financing sources, such as the World Bank.

An foreign organization's aims are comprised of both particular and general priorities (PrettiFrontczak \& Bricker, 2000; Katzenstein et al., 1998). The specific objectives are described in accordance with the organization's characteristics, while the general objectives of international organizations are to establish and maintain world peace and security in a variety of ways determined by each organization and permitted by international law; Participate actively in efforts to improve the welfare of

\section{Kinds of International Organizations}

There are numerous international organizations that can be classified according to their membership category, geographical scope (area), field of action, pattern of cooperation, and work. Below are descriptions and illustrations of each form of organization. The United Nations (UN) or United Nations (UN) is a multinational body that represents the majority of the world's governments. This company was established in San Francisco, California on October 24, 1945, and is headquartered in New York, New York. The United Nations was established to promote international peace, act as a bond between nations, and assist the world community in overcoming global problems such as hunger, illness, and illiteracy, while also respecting human rights and freedoms (Kirkwood-Tucker, 2004; Donnelly, 2013; Mena et al., 2010; Cogan, 2000).

This organization was established on August 8, 1967 in Bangkok, Thailand, as a platform for collaboration between Southeast Asian countries. It now has ten representatives. ASEAN's mission is to create an area of Southeast Asia that is clean, peaceful, healthy, and prosperous.

\section{United Nations Children's Fund (UNICEF)}

This organisation operates under the auspices of the United Nations and was established in New York City on September 11, 1946. UNICEF was established with the mission of eradicating hunger, abuse, disease transmission, and prejudice in the world of children, especially in developed countries. (1) United Nations-sponsored organizations, such as the UNDP, WHO, UNESCO, FAO, UNIFEM, UN-Habitat, and ILO. (2) Organization of the Petroleum Exporting Countries (OPEC); (3) World Trade Organization (WTO); (4) ASEAN Free Trade Area (AFTA); (5) Group of Twenty (G-20); (6) International Committee of the Red Cross (ICRC); (7) International Criminal Police Organization (ICPO-Interpol); (IAACA)

\section{Conclusion}

Based on the information and explanations provided in accordance with the theme, namely the impact and international trade law, it can be concluded that the two are closely related; the impact of international trade will provide both positive and negative outcomes; which, of course, 
will be tailored to maximize positive outcomes and minimize negative outcomes; and, of course, a law is enacted to address the impacts that occur; and, of course, a law is enacted to address the impacts that occur.

\section{References}

Barnet, R. J., \& Cavanagh, J. (1995). Global dreams: Imperial corporations and the new world order. Simon and Schuster.

Bonell, M. J. (2001). Do we need a global commercial code. Dick. L. Rev., 106, 87.

Buthe, T. (2010). Private regulation in the global economy. Business and Politics, 12(3).

Cogan, J. J. (2000). Citizenship education for the 21st century: Setting the context. Citizenship for the 21st century: An international perspective on education, 1-21.

Cutler, A. C. (2002). Private international regimes and interfirm cooperation. Cambridge Studies In International Relations, 85, 23-42.

Donnelly, J. (2013). 13. Human Rights, Democracy, and Development (pp. 217-234). Cornell University Press.

Dubinsky, P. R. (2005). Human Rights Law Meets Private Law Harmonization: The Coming Conflict. Yale J. Int'l L., 30, 211.

Hopkins, M. (2012). Corporate social responsibility and international development: is business the solution?. Earthscan.

Katzenstein, P. J., Keohane, R. O., \& Krasner, S. D. (1998). International organization and the study of world politics. International organization, 645-685.

Kirkwood-Tucker, T. F. (2004). Empowering teachers to create a more peaceful world through global education: Simulating the United Nations. Theory \& research in social education, 32(1), 56-74.

Mavroidis, P. C. (2015). The regulation of international trade: GATT (Vol. 1). MIT Press.

Mena, S., de Leede, M., Baumann, D., Black, N., Lindeman, S., \& McShane, L. (2010). Advancing the business and human rights agenda: Dialogue, empowerment, and constructive engagement. Journal of business ethics, 93(1), 161-188.

Mistelis, L. A. (2000). Regulatory aspects: Globalization, harmonization, legal transplants, and law reform-Some fundamental observations. The International Lawyer, 1055-1069.

Pretti-Frontczak, K., \& Bricker, D. (2000). Enhancing the quality of individualized education plan (IEP) goals and objectives. Journal of early intervention, 23(2), 92-105.

Solórzano, J. S. (2009). An Uncertain Penalty: A Look at the International Community's Inability to Harmonize the Law of Liquidated Damages and Penalty Clauses. Law \& Bus. Rev. Am., 15, 779.

Taruffo, M. (2012). Harmonisation in a Global Context: The ALI/UNIDROIT Principles. In Civil Litigation in a Globalising World (pp. 207-219). TMC Asser Press. 
Waugh, M. E. (2010). International trade and income differences. American Economic Review, 100(5), 2093-2124. 